\title{
Some lesser known fiber yielding weeds used by Gujjar and Bekarwal tribes of District Rajouri, Jammu and Kashmir
}

\author{
Amandeep Singh*, L.R. Dangwal and Tajinder Singh \\ Herbarium and Plant Systematic Lab., H.N.B. Garhwal Central University, S.R.T. Campus, Badshahithaul, \\ Tehri - Garhwal-249199 (Uttarakhand), INDIA \\ *Corresponding author. E-mail:amanguru83@gmail.com
}

Received: January 12, 2014; Revised received: March 20, 2014; Accepted: April 10, 2014

\begin{abstract}
The present communication pertains to some lesser known fiber yielding weeds used by Gujjar and Bekarwal tribe of district Rajouri (J\&K). The study was based on extensive and intensive field surveys conducted in 6 blocks of district Rajouri i.e. Budhal, Rajouri, Thanamandi, Manjakote, Nowshera and Sunderbani. Three sites were selected in each block which was densely inhabited by Gujjar and Bekarwal tribe to document traditional knowledge on fiber yielding weeds. The botanical names of the reported weed species with family, local names and part used have been documented in the present work. During the study period a total of 17 fiber yielding weeds belonging to 2 monocot and 8 Dicot families were reported. Out of total 10 angiospermic families of fiber yielding weeds, the predominance was shown by family Malvaceae having 6 weed species followed by family Tiliaceae and Urticaceae each representing 2 fiber yielding weeds. The study would not only help in documenting the traditional knowledge, it would also help in removal and management of weed species and in promoting growth of major crops.
\end{abstract}

Keywords: Blocks, Families, Fiber, Weeds

\section{INTRODUCTION}

Weeds are generally described as an unwanted obnoxious plants growing in places where they are undesirable (Dangwal et al., 2010). In spite of their negative impact on crops some weeds are of economic importance used by man as food, fodder, fiber, medicines and other miscellaneous purposes (Patil et al., 2007). Fiber yielding weeds hold the second position after edible weeds in their economic importance. They play an important role in human civilization. The ancient man started a nomadic lifestyle by using plant leaves and bark directly to cover his body. Gradually there was advancement in lifestyle and this led him to search for more durable and better material for routine use thus, there began an era of developing different types of textiles, basketories, woven clothes, mats, ropes, coir and cordages material for various uses (Anjula et al., 2003).

The utilization of fiber is directly related to civilization and advancement. Plants have been an important source of fiber since man is using a variety of them for preparing various things like ropes, cords, nets, baskets etc. Till date more than 2000 plants have been worked out which yield fiber (Shanmugam et al., 2012) however, the commercial fiber yielding plants are few in number. Other than textile fiber there are many other fibers derived from plants which are used in preparation of brushes, fishing nets, chair seats and bags etc. (Ant, 2004).

Due to increasing demand of plant fiber there is gradual depletion of forest resources resulted in loss of important diversity. To overcome this problem, there is a need to explore and identify new fiber yielding species to fulfill the demand of raw material for plant fiber based industry. The present study is an effort in this direction that will help in pinpointing the weed species which can be used in making fibers. Further, it would help in documenting the traditional knowledge of Gujjar and Bekarwal tribes and to enumerate and identify the fiber yielding weeds that grow along with the agricultural crops and nearby forests.

\section{MATERIALS AND METHODS}

Study area: The study area is located at western part of Jammu division in the foot hill of Pir panjal range. It lies in between $32^{\circ}-58^{\prime}$ and $33^{\circ}-35^{\prime}$ latitude and $74^{\circ}$ 81 ' longitude at an elevation range of $470-6000 \mathrm{~m}$ above sea level and covering an area of 2630 sq. kilometers.

Collection of data: The present study was conducted to document the traditional knowledge on some lesser known fiber yielding weeds used by Gujjar and Bekarwal tribe of district Rajouri (J\&K).The study was based on extensive and intensive field surveys undertaken in 6 blocks of district Rajouri i.e. Budhal, Rajouri, Thanamandi, Manjakote, Nowshera and Sunderbani during the period August 2009-August 2012. Three sites were selected in each block for field survey to document the traditional knowledge on fiber yielding weeds (Fig. 1). Surveys were undertaken in the remote agricultural villages and forest areas densely inhabited by Gujjar and Bekarwal tribe. During the period of study the farmers and old 


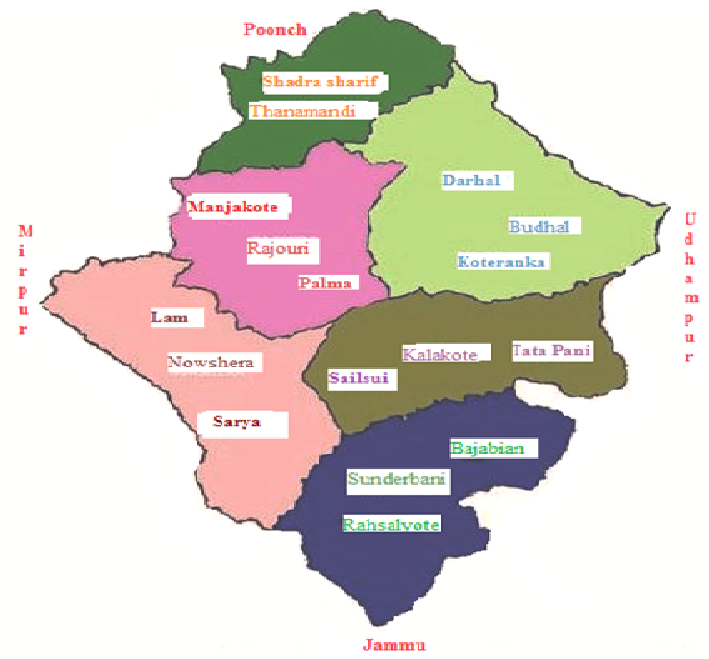

Fig.1.Showing the location map of the study area.

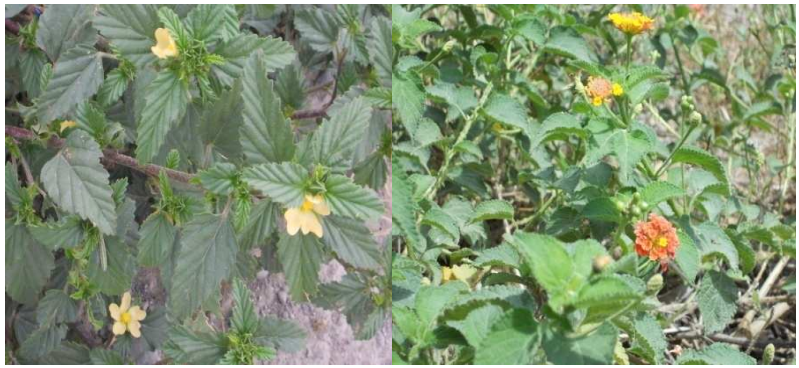

\section{M. coromandelianum}

2. L. camara

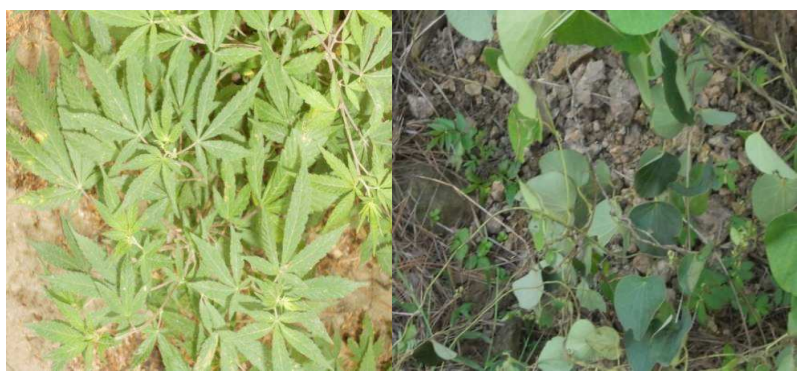

3. C. sativa

4. C. pariera

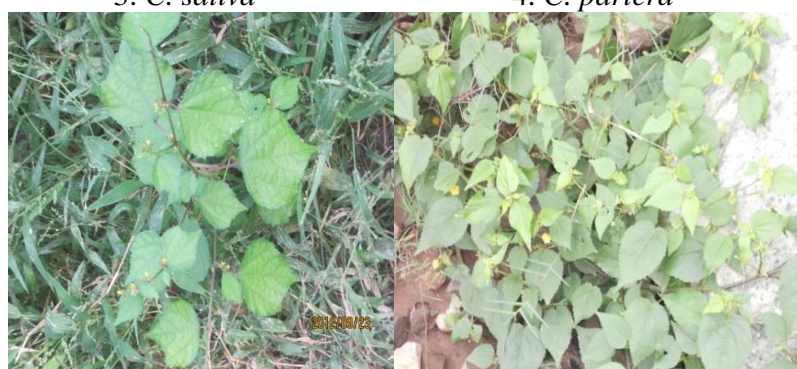

5. T. rhomboidea

6. S. cordata

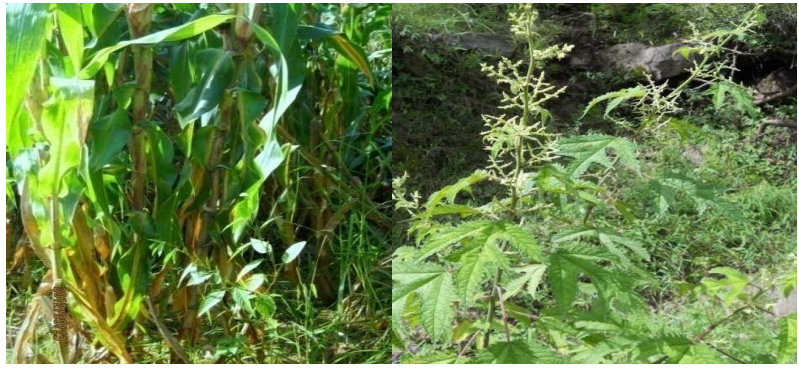

7. C. aestuans

8. G. diversifolia

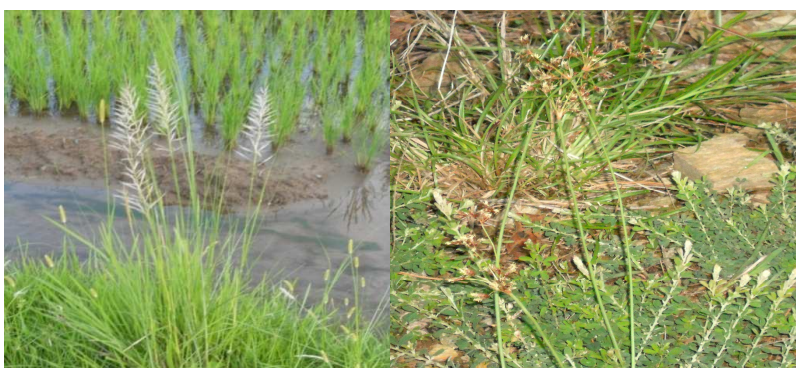

9. S. spontaneum

10. U. dioica

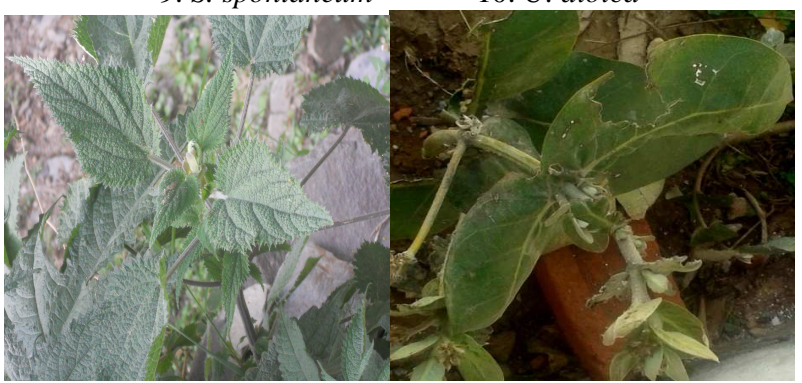

11. E. comosum 12. A. indicum

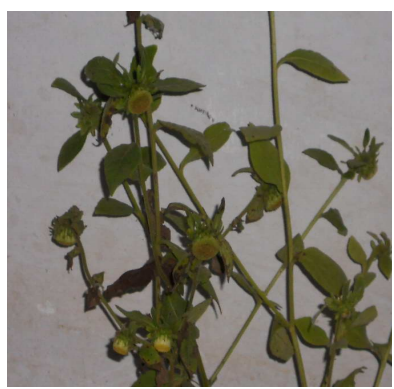

13. A. indicum

Figs. 2. (1-13) Showing fiber yielding weeds captured during the study period.

experienced tribal men and women of each site were interviewed for gaining the first hand knowledge on specific weed species and their parts used in traditional fiber yielding practices. The collected weed plants were pressed, dried, preserved and properly identified with the help of available literature, monographs by Sharma and Kachroo (1983), Swami and Gupta (1998), Kaul (1986) and confirmed from the authentic regional herbaria i.e. Botanical Survey of India, Northern Circle (BSD), Dehradun and Forest Research Institute Herbarium (DD), Dehradun and deposited them in the H.N.B. Garhwal Central University Herbarium, Department of Botany, S.R.T. Campus, Badshahithaul, Tehri Garhwal, Uttrakhand, India.

\section{RESULTS AND DISCUSSION}

The present findings can be correlated with the earlier findings of Shanmugam et al., 2012 who conducted ethno botanical studies on the plants which were used in the preparation of baskets and ropes by Paliyar tribes of Dindigul district of Tamil Nadu and reported a total of 15 fiber yielding plants belonging to 15 genera and 11 families.The study also show 
Table 1. Fiber yielding weeds along with their botanical names available vernacular names and their parts being used.

\begin{tabular}{|c|c|c|c|c|}
\hline S. $\mathbf{N}$. & Family & Botanical name & $\begin{array}{l}\text { Vernacu- } \\
\text { lar name }\end{array}$ & Parts used \\
\hline 1. & Asclepiadaceae & Calotropis procera Aiton. & Chiti aak & $\begin{array}{l}\text { Bark yield fiber which is used in mak- } \\
\text { ing coir and rough nets. }\end{array}$ \\
\hline 2. & Cannabaceae & Cannabis sativa $\mathrm{L}$. & Phang & $\begin{array}{l}\text { Stem yield true hemp fiber used in } \\
\text { making ropes, mats and rough clothes. }\end{array}$ \\
\hline 3. & Cyperaceae & $\begin{array}{l}\text { Eriophorum comosum Wal- } \\
\text { lich }\end{array}$ & Ghass & $\begin{array}{l}\text { The leaves are twisted and bound to- } \\
\text { gether to form a strong rope used to tie } \\
\text { plant material. }\end{array}$ \\
\hline \multirow[t]{6}{*}{4.} & Malvaceae & Abutilon indicum $\mathrm{L}$. & - & $\begin{array}{l}\text { Stem yield strong coarse fiber used in } \\
\text { making ropes and nets. }\end{array}$ \\
\hline & & $\begin{array}{l}\text { Malvastrum coromande- } \\
\text { lianum } \mathrm{L} .\end{array}$ & - & $\begin{array}{l}\text { Stem bark yield fiber used in making } \\
\text { coir and ropes. }\end{array}$ \\
\hline & & Sida acuta Burm. F. & - & $\begin{array}{l}\text { Stem yields a coarse fiber used in mak- } \\
\text { ing rough net and traditional mats } \\
\text { (Chitai). }\end{array}$ \\
\hline & & Sida cordata Burm. F. & - & $\begin{array}{l}\text { Stem is used in making coarse fiber for } \\
\text { preparing rough nets and ropes. }\end{array}$ \\
\hline & & Sida rhombifolia $\mathrm{L}$. & - & $\begin{array}{l}\text { Stem bark is used in making fiber for } \\
\text { weaving ropes and coir. }\end{array}$ \\
\hline & & Urena lobata L. & - & $\begin{array}{l}\text { Stem bark yield a coarse fiber used for } \\
\text { making rough nets and ropes. }\end{array}$ \\
\hline 5. & $\begin{array}{l}\text { Menisper- } \\
\text { maceae }\end{array}$ & Cissampelos pariera $\mathrm{L}$. & Bel & $\begin{array}{l}\text { The wiry stem yields fiber used for } \\
\text { making coir to tie plant material. }\end{array}$ \\
\hline 6. & Poaceae & Saccharum spontaneum L. & Munja & $\begin{array}{l}\text { The mature leaves including small por- } \\
\text { tion of culms are used in making ropes, } \\
\text { pullas (a traditional mat) and brooms. }\end{array}$ \\
\hline 7. & Sterculiaceae & Melochia corchorifolia L. & - & $\begin{array}{l}\text { Bark yield white fiber used for making } \\
\text { cordages. }\end{array}$ \\
\hline \multirow[t]{2}{*}{8.} & Tiliaceae & Corchorus aestuans L. & $\begin{array}{l}\text { Singi } \\
\text { booti }\end{array}$ & $\begin{array}{l}\text { Stem yields a coarse fiber used in mak- } \\
\text { ing coir and net. }\end{array}$ \\
\hline & & Triumfetta rhomboidea Jacq. & - & $\begin{array}{l}\text { Stem yield a soft glossy fiber used for } \\
\text { making rope and decorative items. }\end{array}$ \\
\hline \multirow[t]{2}{*}{9.} & Urticaceae & $\begin{array}{l}\text { Girardinia diversifolia (Link) } \\
\text { Fris. }\end{array}$ & Dang & $\begin{array}{l}\text { Stem yield fiber used for making cord- } \\
\text { ages and sacs. }\end{array}$ \\
\hline & & Urtica dioica $\mathrm{L}$. & $\begin{array}{l}\text { Bichu } \\
\text { ghass }\end{array}$ & $\begin{array}{l}\text { Stem yield strong shining fiber used } \\
\text { for making mats sacs and ropes }\end{array}$ \\
\hline 10. & Verbenaceae & Lantana camara $\mathrm{L}$. & Laaltan & $\begin{array}{l}\text { The fiber from strong wiry basal stem } \\
\text { is used in making traditional baskets. }\end{array}$ \\
\hline
\end{tabular}

correlation with the earlier findings of Anjula et al., 2003 who studied the fiber yielding plants of India along with genetic resources, perspective for collection and utilization and reported a total of 453 plant species belonging to 273 genera and 82 families. During the course of present study a total of 17 fiber yielding weeds belonging to 2 monocot and 8 dicot families have been reported from all the selected sites. Out of total 10 families of fiber yielding weeds the predominance was shown by family Malvaceae having 6 weed species followed by family Tiliaceae and Urticaceae each having 2 fiber yielding weeds. The remaining families i.e Asclepiadaceae, Cannabaceae, Cyperaceae, Verbenaceae, Poaceae, Menispermaceae and Sterculiaceae contained 1 fiber yielding weed (Table 1). The present work is localized to a particular district (small area) so a total of 17 fiber yielding weeds were reported.

District Rajouri is one of the hilly district of J\&K state whose boundaries are attached to district Poonch in north, district Jammu in south, Udhampur in east and Mirpur (Pakistan) in the west. Gujjar tribe constitutes the major proportion of local population leading a nomadic lifestyle. They graze their herds of sheep, goats and cattle from south of Pir- Panjal range to alpine pastures of the greater Himalayan ranges in north. They have their own culture and traditional practices. It has been reported during the study period that these tribe are using 17 weed species for making ropes, coir, nets, rough clothes, cordages, baskets, sacs and pullas (a traditional mats). Being economically poor these tribe mainly depends upon forest and wild sources to fulfill their needs. They utilize the articles prepared from these weeds for their own uses. The 
articles like ropes, coir and baskets are used in agricultural practices and to tie fodder and fuel wood etc.

There are mainly three types of growth forms of fiber yielding weeds collected during the study period i.e herbs, shrubs and climbers. Out of 17 weed species used in traditional practices Calotropis procera, Lantana camara and Urtica dioica are shrubs, Girardinia diversifolia and Cannabis sativa are under shrubs while Cissampelos pariera is a climber, remaining all fiber yielding weeds are herbs. In Dicot families mainly stem bark is used in making fiber while in monocot families leaves are used in making ropes and mats. The study would not only help in documenting the traditional knowledge, it would also help in removal and management of weed species and in promoting growth of major crops. It may also be helpful for taxonomists, agriculturists and scientists involved in the management of weeds. Further commercial exploitation of the fiber yielding weeds through proper research and development activities will help in upliftment of these tribal societies.

\section{Conclusion}

A total of 17 weed species mostly from agricultural fields and nearby forests were reported to be used in traditional practices for extracting fibers. Some of the articles prepared from these weeds are sold in the local market which contribute to the income of these tribes. Moreover, by identifying and adopting large number of wild weeds and allied species, supplementing to fiber requirement can reduce the pressure on natural forests and may also be helpful in management of weeds from agricultural fields.

\section{REFERENCES}

Anjula, P. and Gupta, R. (2003). Fiber yielding plants of India, genetic resources perspective for collection and utilization. Nat. prod. Radi., 12(4): 194-204.

Ant, H.M. (2004). Some fiber yielding plants used for the preparation of ropes in Bhanaskantha district, North Gujarat. Adv. in P. Sci., 17(2): 443-445.

Dangwal, L.R., Singh, A., Singh, T., Sharma, A. and Sharma, C. (2010). Common weeds of Rabi (Winter) crops of Tehsil Nowshera District Rajouri (J\&K), India. Pak. J. Weed Sci. Res., 16(1): 39-45.

Kaul, M.K. (1986). Weed flora of Kashmir Valley. Scientific Publishers, Jodhpur, Inda.

Patil, D.A., Patil, M.V. and Shubhangi, P. (2007). Edible weeds of tribals of Jharkhand Orissa and West Bengal. Ind. J. of Trad. Know., 6(1):217-222.

Shanmugam, A., Muthuraja, G., Annadurai, M., Dhanasekaran, M. and Gobinathan, S. (2012). Ethno botanical study on the plants used for the preparation of baskets and ropes by Paliyar tribes of Pachalur in Dindigul District of Tamil Nadu, India. Life Sci. Leaflets, 4: 27-30.

Sharma, B.M. and Kachroo, P. (1981). Flora of Jammu and Plants of Neighbourhood. Bishen Singh, Mahendra Pal Singh, Dehradun.

Swami, A. and Gupta, B.K. (1998). Flora of Udhampur. Bishen Singh, Mahendra Pal Singh, Dehradun. 